\title{
Factors affecting mortality in patients with burns
}

\section{Yanıklı hastalarda mortaliteye etkili faktörler}

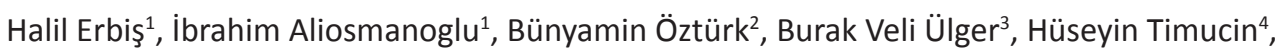
Mehmet Akif Türkoğlu ${ }^{1}$, Veli Vural ${ }^{1}$

\begin{abstract}
Objective: The increase in life quality and expectancy causes an increase in the elderly population. Improvements in burn treatment resulted in decreased mortality in children and young adults but in elderly patients burns are still an important trauma that should be handed differently than other age groups. The aim of this study was to evaluate the factors effecting mortality in patients with burns over 45 years old.
\end{abstract}

Methods: Fifty-eight patients over 45 years of age, who were treated in our burns unit in the last 3 years were included in our study. Their age, burn percentage and depth, coexisting diseases and mortality rates were examined retrospectively.

Results: The average age of surviving patients was 57.4 years while it was 70 years for nonsurviving patients $(p=0.002)$. The width of burn area was $21.1 \%$ in surviving and $50 \%$ in nonsurviving patients $(p<0.01)$. The effect of additional coexistent diseases on mortality was significant $(p=0.001)$. The most common reasons of mortality were sepsis and congestive heart failure.

Conclusion: We found out that the age, percentage of burns and coexistent diseases had a negative effect on success of treatment and mortality. Mortality rates will decrease in these cases with careful follow-up and a multidisciplinary approach. J Clin Exp Invest 2015; 6 (3): 240-243

Key words: burns, coexisting, mortality, elderly patient

\section{INTRODUCTION}

The increase in life quality and expectancy causes an increase in the elderly population. Burns, in this age group, are an important trauma that should be handed differently than other age groups. Burns

\section{ÖZET}

Amaç: Yaşam kalitesi ve tıbbi tedavi imkanlarının artma$\mathrm{SI}$, yaşlı hasta nüfusunda bir artışa neden olmuştur. Yanık tedavisindeki gelişmeler çocuklarda ve genç erişkinlerde yanığa bağlı mortalitede azalmaya neden olmuştur, ancak yaşılardaki yanıklar, diğer yaş gruplarından farklı şekilde ele alınması gereken önemli bir travmadır. Bu çalışmanın amacı 45 yaşın üzerindeki yanıkı hastalarda mortalite üzerine etkili faktörleri değerlendirmektir.

Yöntemler: Son 3 yıl içerisinde yanık ünitemizde tedavi edilen 45 yaş üzerindeki 58 hasta çalışmaya dahil edildi. Hastaların yaşları, yanık oranları ve yanıklarının derinliği, eşlik eden hastalıklar ve mortalite oranları retrospektif olarak değerlendirildi.

Bulgular: Mortalite gelişmeyen hastaların ortalama yaşı 57,4 yıl iken, mortalite gelişenlerinki 70 yıl idi $(p=0,002)$. Ortalama yanık genişliği mortalite gelişmeyenlerde \% 21,1 iken, mortalite gelişenlerde $\% 50$ idi $(p<0,01)$. YanıkIı hastalarda eşlik eden hastalık bulunmasının mortalite üzerine anlamlı etkisi olduğu saptandı $(p=0,001)$. Mortalitenin en önemli nedeni sepsis ve konjestif kalp yetmezliği idi.

Sonuç: Çalışmamızın sonuçları yanık alanının yüzdesinin ve eşlik eden hastalıkların varlığının tedavi başarısı ve mortalite üzerine olumsuz etkileri olduğunu gösterdi. $\mathrm{Bu}$ hastalarda multidisipliner yaklaşım ve yakın takip ile mortalite oranlarının düşeceğini düşünmekteyiz.

Anahtar kelimeler: Yanıklar, eşlik eden hastalıklar, mortalite, yaşlı hastalar

are serious cases that create serious physical and mental problems that can cause death or disabilities. Despite medical and technological progress, burns are serious problems that still threaten lives [1]. Therefore, the cheapest and the most effective

\footnotetext{
${ }^{1}$ Department of General Surgery, Medical Faculty, Akdeniz University, Antalya, Turkey

${ }^{2}$ Department of Anesthesiology Faculty of Medicine, Akdeniz University, Antalya, Turkey

${ }^{3}$ Department of General Surgery, Medical Faculty, Dicle University, Diyarbakır, Turkey

${ }^{4}$ Department of General Surgery, Education and Research Hospital, Şanlıurfa, Turkey
}

Correspondence: Halil Erbiş,

Akdeniz University Medical Faculty, Department of General Surgery, Antalya, Turkey Email: halilerbis@hotmail.com

Received: 12.08.2015, Accepted: 28.09.2015

Copyright @ JCEI / Journal of Clinical and Experimental Investigations 2015, All rights reserved 
method is preventing the burns with precautions taken beforehand [2].

In the last 20 years, important improvements were made in the treatment of burns victims. Especially in the children and young adult population, burn victims of almost all width and depth can survive [3]. Conversely, the treatment results in elderly victims are quite unsuccessful compared to the childhood and young adulthood [4-6]. The most important causes of this situation include chronic diseases, which are common amongst the elderly, decreased cardiopulmonary reserves and a tendency to infections and sepsis $[7,8]$. This is why an aware and multidisciplinary approach is necessary starting from the early phases in the burns in this age group.

The aim of this study was to evaluate the factors effecting mortality in patients with burns over 45 years old.

\section{METHODS}

A total of 58 patients older then 45 years old who were treated at the burns unit of our hospital between July 2009 and May 2014 were included in this study. The age limit was set as 45 because the decrease in survival rates increases after this age [4].

The patients' files were analyzed retrospectively. The ages, genders, burn reasons, width of burns, coexistent systemic diseases, durations of hospital stays and mortality rates of the patients were evaluated. The treatment protocols at the patients' admission and during their clinical follow up were standardized, including all stages of resuscitation, antibiotherapy, wound care and surgical operations.

In all patients, liquid resuscitation was arranged according to the parkland formula. In the nutritional support treatment, the protein and calorie needs of the patients were given orally or parenterally. Antibiotic treatment was based on the general microbial flora of the infection.

\section{Statistical Analysis}

In the evaluation of the study results, SPSS (Statistical Package for Social Sciences) Windows 11.5 program was used for statistical analysis. The quantitative data were indicated as mean \pm standard deviation. Kolmogorov-Smirnov test was utilized for the compatibility of normal distributed data. In comparison of the groups, Mann Whitney- $U$ test was used in analysis of non-parametric data, while Chisquare test was used in the analysis of categorical data. $P$ values $<0.05$ were accepted to be significant for all variables.

\section{RESULTS}

Of the patients included in the study, $31(53.4 \%)$ of them were male and $27(46.6 \%)$ were female. The mean age of the patients was $58.9 \pm 12.4(45-88)$ years. All of the patients had both second and third degree burn areas (Figure 1).

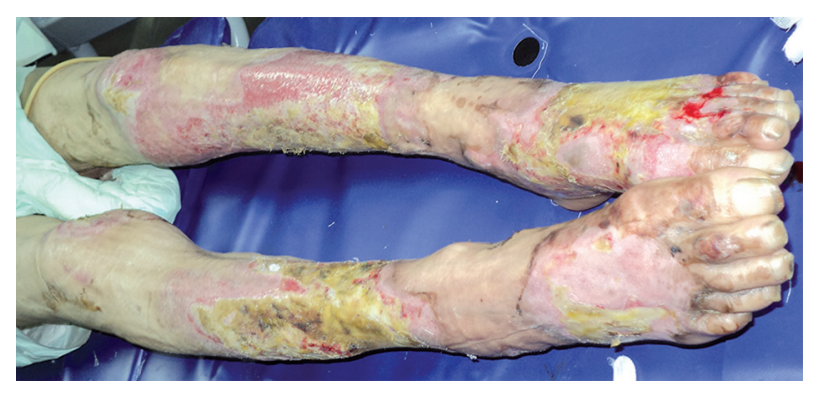

Figure 1. A patient with flame burn

The reasons of burns were categorized under four main groups; flame, electricity, boiling water and chemicals. The demographic data and mortality rates are given in Table 1 . The effect of gender and burn etiology on patients mortality wasn't statistically significant ( $p=0.07, p=0.11$, respectively). The effect of additional coexistent diseases on mortality was significant $(p=0.001)$.

Table 1. Demographic characteristics of the patients

\begin{tabular}{lc}
\hline Demographic Features & $\mathbf{n}(\%)$ or Mean \pm SD \\
\hline Age (years) & $58.9 \pm 12.4(45-88)$ \\
Gender & $31(53.4)$ \\
Male & $27(46.6)$ \\
Female & $24.6 \pm 13.2(10-80)$ \\
Width of burn (BSA) & $13(22.4)$ \\
Etiology & $8(13.8)$ \\
Flame burn & $29(50)$ \\
Electric burn & $8(13.8)$ \\
Boiling water burn & \\
Chemical burns & $58(100)$ \\
Surgical intervention & $53(91.4)$ \\
Debridement & $7(12.1)$ \\
Greft & $25.1 \pm 11.1(6-56)$ \\
Mortality &
\end{tabular}

SD: Standard deviation, BSA: Body surface area 
Survival rates were lower in patients with congestive heart failure. The survival rates of additional systemic diseases were shown in Table 2. It was discovered that the width of the burn and the age of the patients were effective on mortality, independent of other variables. The mortality rates according to patients' ages and the width of their burns are shown in Table 3. The duration of hospital stays were shown in Table 3. All of the nonsurviving patients were lost in the first two weeks. The mortality reasons of these 7 patients were sepsis in four, cardiac arrest in two and multiple organ failure in one.

Table 2. Coexisting diseases and survival

\begin{tabular}{lcc}
\hline & $\begin{array}{c}\text { Number of } \\
\text { patients }\end{array}$ & $\begin{array}{c}\text { Mortality } \\
(\%)\end{array}$ \\
\hline Hypertension & 9 & 0 \\
Diabetes mellitus & 10 & 25 \\
Congestive cardiac failure & 5 & 100 \\
COPD & 5 & 0 \\
\hline
\end{tabular}

COPD: Chronic obstructive pulmonary disease

Table 3. Mortality rates according to patients' ages and the width of their burns

\begin{tabular}{lccc}
\hline & $\begin{array}{c}\text { Alive } \mathbf{n}(\%) \text { or } \\
\text { Mean } \pm \text { SD }\end{array}$ & $\begin{array}{c}\text { Died } \mathbf{n}(\%) \text { or } \\
\text { Mean } \pm \text { SD }\end{array}$ & p \\
\hline Age (years) & $57.4 \pm 11.2$ & $70 \pm 16.1$ & 0.002 \\
Width of burn (BSA) & $21.1 \pm 8.5$ & $50 \pm 14.5$ & $<0.001$ \\
$\begin{array}{l}\text { Duration of hospital } \\
\text { stay(days) }\end{array}$ & $26.6 \pm 10.7$ & $11.8 \pm 3.1$ & $<0.001$ \\
Coexisting & $22(43.1)$ & $7(100)$ & 0.005 \\
\hline
\end{tabular}

SD: Standard deviation, BSA: Body surface area

\section{DISCUSSION}

Despite the more developed resuscitation principles, wound care and surgical techniques in recent years, burns trauma in the elderly is still an important cause for morbidity and mortality $[1,9,10]$. Due to declining ability in motor functions and reflexes, elderly patients are exposed to burns more often. On the other hand, in elderly patients who are not good to accommodate to stress and presence of coexistent diseases are effecting burns treatment and treatment results in a negative way [11]. In studies conducted, burns are noted to be at $4^{\text {th }}$ place in geriatric patients' death due to injuries [12]. In this patient group, mortality rates according to burns area is much higher than expected compared to younger patients. While in young adults $80 \%$ burns area causes $50 \%$ mortality, between ages $60-70$,
$35 \%$ burns area results in the same mortality rate. Above age of 70 even $20 \%$ burns area causes $50 \%$ mortality $[7,13]$. In our study, patients' average age was 58.9 , burnt area was $24.6 \%$ and mortality rate was determined as $7 \%$. Most of the nonsurviving patients were 70 years old or over. Mean burn rate was established as $24.2 \%$ and mortality rate as $35.7 \%$ over age of 70 . In studies it is noticed that in this age group etiology of burns was mostly flame and boiling water burns [14-16].

Electricity and chemical burns are seen less in this group of patients. The reason might be that during a fire or a kitchen accident, elderly patients have a smaller ability to run and save themselves, due to their diminished reflexes. In our study, boiling water burns were the most common, followed by flame burns. The width of the burnt area is one of the most important parameters indicating the magnitude of the burn. Also in our study, the relationship between the width of the burns and mortality attracts attention. In surviving patients, there was an average of $21.1 \%$ percent burn width while this was $50 \%$ in nonsurviving ones $(p<0.01)$. In this age group, an important part of patients have coexisting diseases. Wibbenmeyer et al., [7] did not detect a negative effect of coexisting diseases on mortality in a study they conducted, whereas Rao et al [14] discovered an important relationship between coexisting diseases and mortality. In our study, we also found a higher mortality rate in patients with coexisting diseases $(p=0.005)$. Especially in patients with congestive heart failure, mortality was higher. As a possible reason, this might be because the body cannot adapt to liquid resuscitation and changing body fluid dynamics with heart diseases. Like the other studies, the most common mortality reason was sepsis.

The second most common reason was determined to be cardiac arrest. In elderly patients with burns, the time of operation is controversial. We preferred "early burn debridement" (excision) and grafting in third degree burns where the patient was stabile and there were no inhalation injuries. In second degree burns, we decided on debridement according to the daily following of wounds.

In conclusion, we observed that age, percentage of burns and coexisting diseases have a negative effect on treatment success and mortality. Patients from this age group, which hold the highest mortality rates in burns, require special attention in their treatment and follow ups due to their coexistent diseases and the general negative effects of old age on all systems. We think that mortality rates will de- 
crease in these cases with careful following and a multidisciplinary approach.

\section{REFERENCES}

1. Masud D, Norton S, Smailes $S$, et al. The use of a frailty scoring system for burns in the elderly. Burns 2013 ;39:30-36.

2. Aliosmanoğlu C, Aliosmanoğlu I, Kapan M, et al. Treatment and follow-up results of children with electrical burn who observed in burn intensive care unit. Dicle Medical Journal 2011;38:170-173.

3. Barret P. The Small Burn. In: Barret P, Herndon N. Principles and practices in burns surgery. New York: Marcel Dekker 2005;187-220.

4. Saffle JR, Larson CM, Sullivan J, Shelby J. The continuing challenge of burn care in the elderly. Surgery 1990;108:534-543.

5. Redlick F, Cooke A, Gomez M, et al. A survey of risk factors for burns in the elderly and prevention strategies. J Burn Care Rehabil 2002;23:351-356.

6. Kara M, Peters WJ, Douglas LG, Morris SF. An early surgical approach to burns in the elderly. J Trauma 1990;30:430-432.

7. Wibbenmeyer LA, Amelon MJ, Morgan LJ, et al. Predicting survival in an elderly burn population. Burns 2001;27:583-590.
8. Colohan SM. Predicting prognosis in thermal burns with associated inhalational injury: a systematic review of prognostic factors in adult burn victims. J Burn Care Res 2010;31:529-539.

9. Ryan CM, Schoenfeld DA, Thorpe WP, et al. Objective estimates of the probability of death from burn injuries. N Engl J Med 1998;338:362-366.

10. Godwin Y, Wood SH. Major burns in Cape Town: a modified burns score for patient triage. Burns 1998;24:58-63.

11. McGill V, Kowal-Vern A. Gamelli RL. Outcome for older burn patients. Arch Surg 2000;135:320-325.

12. Porro LJ, Demling RH, Pereira CT, Herndon DN. Care of geriatric patients. In: Herndon D. Total Burn Care (Fourth Edition). London: Saunders 2012;415-419.

13. O'Neill A, Rabbits A, Hamel H, Yurt R. Burns in the elderly; our burn centers experience with patients over 75 years old. J Burn Care Rehabil 2000;21:183.

14. Rao K, Ali SN, Moiemen NS. Aetiology and outcome of burns in the elderly. Burns 2006;32:802-805.

15. Ho WS, Ying SY, Chan HH. A study of burn injuries in the elderly in a regional burn centre. Burns 2001;27:382-385.

16. Yolcu S, Beceren NG, Timuçin H, Uludağ U. Emergency service admissions of patients with burn injury. J Clin Exp Invest 2013;4:285-288. 